\title{
ENTRE LA TRADICIÓN Y LA ANTIPOESÍA: "DEFENSA DE VIOLETA PARRA"
}

\section{Elvira Santana DubreuiL $L^{* *}$}

\section{RESUMEN}

Se postula que los modelos de las estructuras clásicas grecolatinas fijaron paradigmas en la literatura, los que permanecen hasta nuestros días. Improntas posibles de descubrir pese a las innovaciones que le ha impuesto el artista en su afán de creación y que, a través del tiempo, constituyen la dinámica cultural. Es el caso de la estrofa sáfica adónica, siglo VI a.C., presente en el poema de Nicanor Parra "Defensa de Violeta Parra", el que se examina en esta investigación.

Palabras claves: Modelo clásico, tradición, innovación, recreación.

\section{ABSTRACT}

This paper proposes that the models of classical Greek and Latin structures are fixed paradigms in literature that remain up to the present. It is possible to discover these structures in spite of the innovations that the artist has imposed in the creative process and which, over time, constitute the dynamics of culture. It is the case of sáfica adónic verse, VI B.C., mentioned in Nicanor Parra's poem "Defensa de Violeta Parra", examined in this research.

Keywords: Classical model, tradition, innovation, recreation.

Recibido: 05.04.2005. Aprobado: 05.01.2006.

* Bachiller en Literatura Hispana y Profesora de Estado en Castellano por la Universidad de Chile (1984). Investigadora. E-mail: elvsantana@yahoo.com 


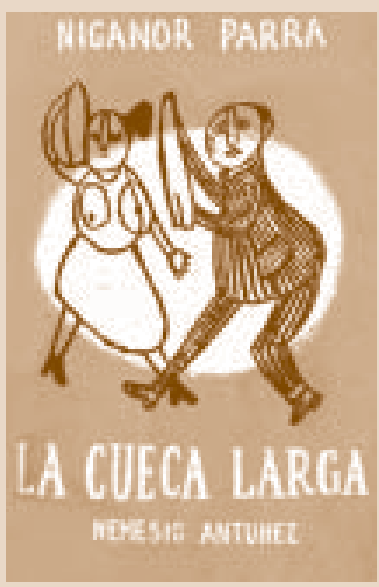

\section{INTRODUCCION}

T A ABUNDANTE bibliografía existente acerca de la poética de Nicanor Parra inhibe realizar cualquier intento de agregar algo nuevo sobre la materia, sometida a gran cantidad de análisis, partiendo sólo de su denominación antinómica de "antipoesía". Maximino Fernández (1980: 107131; 1984: 141-147 y 1985: 137-161) totaliza la no despreciable suma de más de mil trescientas fichas bibliográficas sobre la poética de Nicanor $\mathrm{Pa}-$ rra, advirtiendo que no pretende ser exhaustivo en su inventario, pues supone debe existir más información en publicaciones extranjeras, especialmente en tesis universitarias y trabajos de investigación de éstas en otros países. A lo anterior debe sumarse la publicación de libros con acuciosos estudios sobre la antipoesía parriana publicados con posterioridad a la bibliografía precitada de Fernández, como la de Iván Carrasco: Para leer a Nicanor Parra (1999) y otros.

No obstante lo anterior, me exigió agregar unas hojas más a la fronda de estudios parrianos el descubrimiento de identidades textuales entre los dos primeros versos del poema "Defensa de Violeta Parra" con los dos versos, también iniciales, de "Oda al céfiro", del poeta humanista renacentista Esteban Manuel de Villegas, 1589-1669 (1913: 349), ya que se observa, además de esta identidad, la asimilación del modelo métrico y estrófico de la citada oda, con las modificaciones que se señalarán en el desarrollo de la investigación.

El teórico y crítico italiano Cesare Segre, en su obra Principios deanálisis del texto literario (1984: 94), denomina intertextualidad a la presencia de textos anteriores en un texto determinado o la utilización explícita o camuflada de fuentes o citas, lo que opone a la plurivocidad, pues mientras la primera "sólo se restringe al texto poético, la segunda, la plurivocidad, corresponde más a la novela, ya que pertenece al ámbito de la lengua".

Postulamos que Parra hace uso tanto de intertextualidades como de plurivocidades, pues la peculiaridad de su poética es justamente la mixtura del verso propiamente lírico con los lugares comunes del habla coloquial.

El poema "Defensa de Violeta Parra" en su versión original fue publicado por la Editorial de la Universidad de Buenos Aires, en una recopilación hecha por Margarita Aguirre, bajo el título de La cueca larga (1958), cuyo prólogo compartió con Juan Agustín Palazuela. Este se presenta con 16 estrofas sáficas adónicas, la última de las cuales rompe la estructura señalada con una sáfica adónica de mayor cantidad de versos, pero que mantiene su formalidad versal, aun cuando se encuentran algunas estrofas fragmentadas o diseminadas. 
En cuanto a su mensaje, es claro y directo; como lo señala su título, es una "defensa" de Violeta por los motivos que todos conocemos: el no tener ella un reconocimiento oficial ni extraoficial y menos la comprensión ni ayuda en su afán fundamental de descubrir y difundir las expresiones más auténticas de nuestra cultura. Además, realza los méritos personales de Violeta, haciendo una enumeración de los muchos oficios que cumple a las "mil maravillas".

La segunda versión del poema, objeto de esta investigación, se publica en O bra gruesa, Editorial Universitaria (1969: 172-7); la "defensa" de Violeta se ha transformado en una "elegía" ante la trágica muerte de su hermana, el 5 de febrero de 1967. El poema original, de 16 estrofas, se extiende ahora a 31, todas de estructura sáfica adónica, pero éstas se encuentran en su mayoría fragmentadas o diseminadas.

La antipoesía se declara rupturista con las poéticas tradicionales, por lo que me pareció interesante investigar si los elementos trasladados como intertextualidades se asimilaron para establecer una base métrica tradicional, de lo que resultaría estar en presencia de un antipoema cuyo modelo formal se remonta a la antigüedad griega, resucitado en el Renacimiento y vigente aún en nuestros días.

Para despejar la incógnita del problema planteado se revisarán brevemente los siguientes aspectos referidos a la métrica tradicional sáfica adónica y a la de la antipoesía en estudio:

a) Trayectoria histórica de la estrofa sáfica adónica.

b) El texto del poema frente a la antipoética parriana.

c) Forma de asimilar el modelo métrico sáfico adónico en el antipoema.

En síntesis, se pretende confirmar la tesis del lingüista ruso Ivanov V.V. y otros, citado por C. Segre (1984: 164), cuando aborda la "Historia y modelos", donde establece lo siguiente:

En la conexión de niveles y subconjuntos diversos en aquel todo semiótico que es la "cultura", operan dos mecanismos contrarios entre sí:

a) La tendencia a la variedad, o sea el aumento de los lenguajes semióticos diferentemente organizados, el "poliglotismo" de la cultura.

b) La tendencia a la uniformidad, o sea la tendencia de la cultura para interpretarse a sí misma o a las otras culturas como lenguajes unitarios, rigurosamente organizados.

De lo anterior resulta una diacronía en una sincronía que promueve la experiencia de lo "diferente", cuyo resultado es constitutivo de toda cultura.
NICANOR PARRA

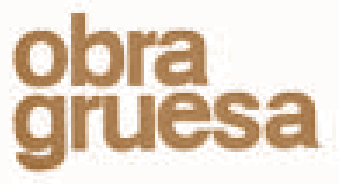




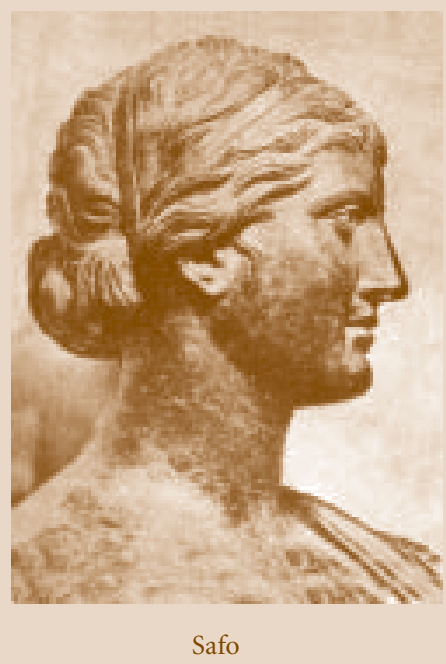

Safo

\section{BREVE TRAYECTORIA HISTORICA DE LA ESTROFA SAFICA ADONICA}

Las formas líricas tradicionales persisten cual misterioso atavismo a través de los siglos, aflorando en las generaciones sucesivas como un desafío estético consistente en superar la impronta de los clásicos. Así ocurre con una de las formas poéticas más antiguas como es la estrofa sáfico o sáfica adónica, cuyo origen se remonta a la antigüedad griega, al siglo VI a.C., en la isla de Lesbos, en donde vivió Safo, la inspirada poeta que le dio su nombre y quien con uno de los metros líricos más armoniosos enriqueció la poesía griega y, a través de ella, la latina, la que a su vez la traspasaría a las poéticas de las lenguas romances.

La obra completa de Safo, desgraciadamente, nunca la conoceremos: el tiempo, las guerras, la carencia de una percepción futurista frente al patrimonio cultural, permitieron que, de sus nueve libros de odas, sólo se rescataran unos cuantos fragmentos, conocidos gracias a otros grandes de las letras griegas, quienes incluyeron en sus obras de historia e investigación literaria las creaciones de esta gran poeta. Así hemos podido conocer fragmentos de su poesía por Aristóteles, Plutarco, Ateneo, Hephestión. Longino es quien cita extensamente "Oda a una mujer amada" en su Tratado de lo sublime y Dionisio de Halicarnaso comenta y rescata su "Oda a Afrodita" que figura en una selección de Poetas líricos griegos (1884: 287).

Oh tú en cien tronos Afrodita reina,

Hija de Zeus, inmortal, dolosa:

No me acongojes con pesar y tedio

Ruégote, Cipria!

(Versión castellana de M. Menéndez Pelayo)

Anacreonte fue el heredero más cercano de Safo en el tiempo y en el espacio. Nacido en Teos o Teyos, ciudad de Jonia, por los años 560 a.C., su larga y azarosa vida lo llevó a diferentes lugares, entre éstos a la isla de Sámos, a donde llegó huyendo de los persas, quienes habían invadido Jonia. Después de la muerte del príncipe tirano que lo favorecía allí, Anacreonte se trasladó a Atenas, llamado por Hiparco, hijo del tirano Pisístrato. A Hiparco, amante de las letras, Anacreonte debió muchos honores y no habría regresado a su patria si el hecho histórico de la conjuración de Armodio y Aristógiton no le hubiesen privado de su príncipe protector.

Los atenienses conservaron la memoria de Anacreonte en una estatua cercana a la de Pericles, la que lo representaba en ademán de un beodo cantando, ya que siempre consideró al vino como el creador de la alegría; en estrofas sáficas cantó al amor, a la alegría y a los dioses: 
Tú, que das caza a los veloces ciervos,

Hija de Jove, de cabello blondo,

Diana, señora de alimañas fieras,

Oye mi ruego.

(Fragmento, versión castellana de F. Baraibar, directamente del griego (Halicarnaso, 1884)).

Le correspondió al príncipe de los poetas, Horacio, trasladar con éxito la estrofa griega a la poesía latina. Catulo también ensayó el verso sáfico e imitó el poema de Safo "Oda a la mujer amada".

En la resurrección de la Antigüedad clásica grecolatina del Renacimiento, las formas sáficas tuvieron su lugar, pero no se puede decir que fue una composición común de los poetas renacentistas. En este período los poetas españoles le agregaron el adorno de la "asonancia". El arzobispo de Tarragona Antonio Agustín, en 1540, fue el primero que empleó en castellano la forma métrica sáfica al traducir en Italia, hasta donde llegó para estudiar los metros clásicos, su conocida "Oda a la paloma". Con posterioridad, siempre en el siglo XVI, otros dos grandes latinistas religiosos: Francisco Sánchez de las Brozas, conocido como el Brocense, empleó la estrofa sáfica adónica en su traducción de la oda "Rectius vives" de Horacio y más tarde Jerónimo Bermúdez intercaló tres composiciones en estrofas sáficas en los coros de Nise Lastimosa, Actos II y III y en el III Acto de Nise Laureada, aunque con algunas variantes de acentuación, según lo indica Tomás Navarro en sus estudios de M étrica española (1956: 192-193).

Las estrofas sáficas adónicas continuaron a través del tiempo. En el siglo XVI se destaca Baltazar de Alcázar (1530-1606), poseedor de una amplia cultura, conocía el latín y el italiano, aficionado a la música, sus poemas tenían la alegría de Sevilla, su tierra natal. Es conocida su humorística sátira contra el "Amor", en versos sáficos. Pero, sin duda, el poeta que logró mayor éxito con la métrica sáfica adónica fue Esteban Manuel de Villegas, nacido en Matute, cerca de Nájera, en 1589 y fallecido en 1669. Se le llamó "El Cisne de Najerilla" " "El Anacreonte español", pues sus traducciones directamente del griego de la poesía anacreóntica no han sido jamás superadas. Sus estrofas sáficas adónicas bastarían para darle el calificativo de altísimo poeta, reconocido por el propio Lope de Vega, quien, refiriéndose al incidente que originó la primera edición del libro de Villegas Eróticas y amatorias, 1617 -cuya portada rezaba: "me surgente quid istae", frase que la censura lo obligó a retirar por estimarla ofensiva para los lectores-, en abierta alusión a la vanidad -rasgo que definía el carácter de Villegas-, escribió aludiendo el hecho en su obra El laurel de Apolo, que se menciona en una nueva edición de Esteban Manuel de Villegas (1913: 349).

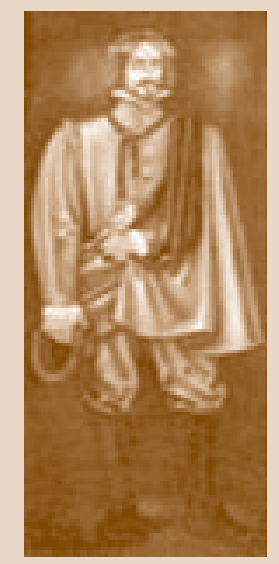

E.M. de Villegas

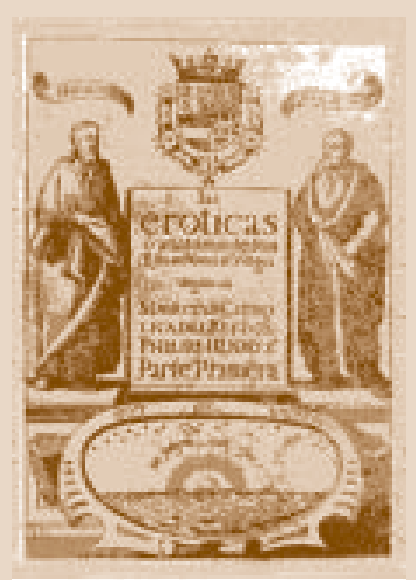




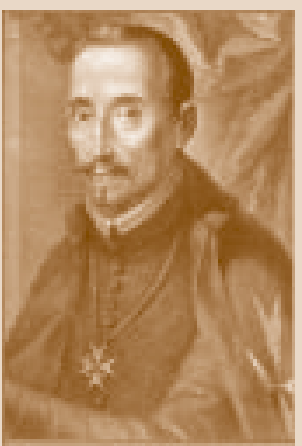

Lope de Vega

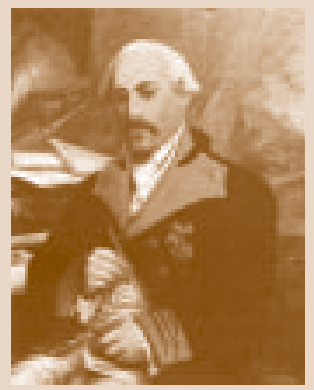

J. Cadalso

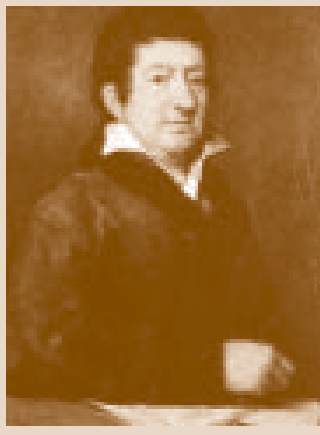

L. de Moratín
Aspire luego del Pegaso el monte, el dulce traductor de Anacreonte, cuyos estudios con perpetua gloria librarán del olvido su memoria, aunque dijo que todos se escondiesen cuando los rayos de su ingenio viesen.

Villegas tuvo una larga y esmerada formación clásica, traductor del griego y del latín, lo que sumado a su natural talento poético hizo de la estrofa sáfica adónica una verdadera recreación lírica; conocida es su "Oda al Céfiro", la que más adelante se va a ver como una intertextualidad en el inicio del poema de N. Parra, objeto de este estudio.

Con posterioridad a Villegas, en el siglo XVIII, neoclásico de la España ilustrada, surgen varios cultores de las formas métricas sáficas: José Cadalso, Nicolás y Leandro Moratín, Juan Meléndez Valdés, Manuel María de Arjona, Martínez de la Rosa, Arolas, Cobanyes y otros. Se debe mencionar en forma especial al más importante en este momento: José María Vaca de Guzmán, quien escribió con estricto apego a las formas clásicas de los sáficos adónicos en su "Oda a la muerte de Cadalso" (Vaca de Guzmán, 1869: 226). El verso sáfico transforma en oda lo que correspondería por su contenido a una elegía, como una forma de respeto a la idea clásica de la utilización de la estrofa sáfica siempre en odas. Cadalso ya había escrito una larga elegía de veintiséis estrofas sáficas adónicas a la muerte de su amante, la actriz María Ignacia Ibáñez, que figura en la precitada recopilación de poetas líricos:

De negro luto me vestí llorando y de cipreses coroné mi frente Eco doliente me llevó con quejas Hasta su tumba.

En el Romanticismo la estrofa sáfica mantuvo el apogeo del siglo anterior y muchos poetas cultivaron esta métrica. Navarro (1956: 344) cita a Zorrilla en su poema "Ay de mi Alhama", a Bermudes de Castro en "Canto sáfico", a Avellaneda en "Canto matutino a la Virgen", a Juan León Mera en su oda "A la estatua de Bolívar", a Ventura de la Vega en el "Himno a Luperco de la muerte del César" y muchos otros largo de enumerar aquí.

Resulta curioso que Navarro (1956: 344) haga especial referencia en sus estudios de métrica de este período al poeta chileno Salvador Sanfuentes, quien figura en la Antología general de la poesía chilena (Silva Castro, 1959: 47-61), con la observación de haber introducido "la modificación poco afortunada de dar rima aguda al segundo endecasílabo y al pentasílabo final: AEBé, en un pasaje de su poema 'El campanario'". El extenso poema del discípulo de Bello cuenta con ochenta estrofas, de las cuales solamente ocho son sáficas adónicas: 


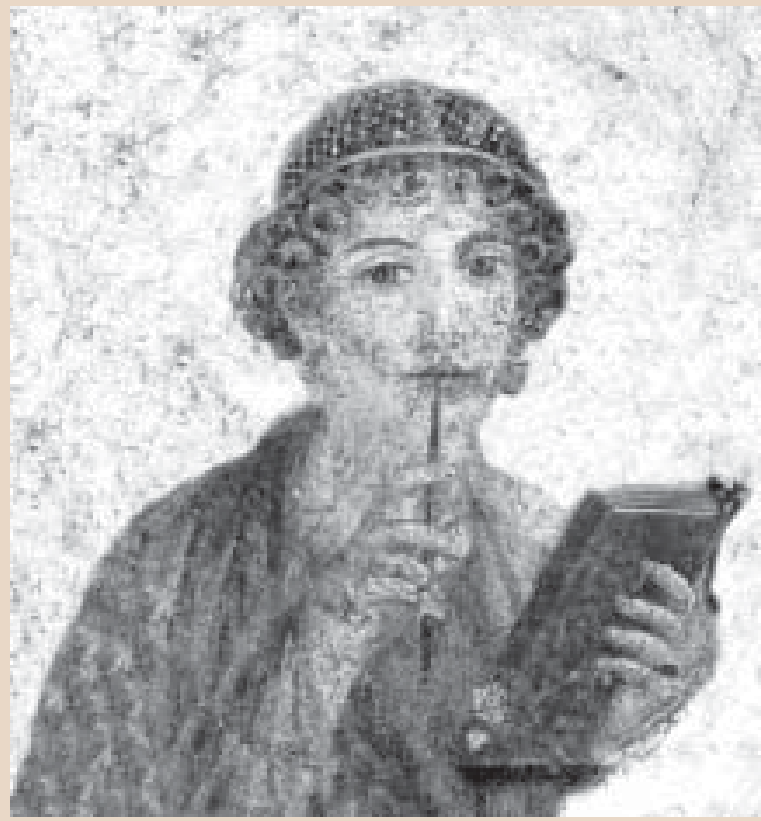

Safo

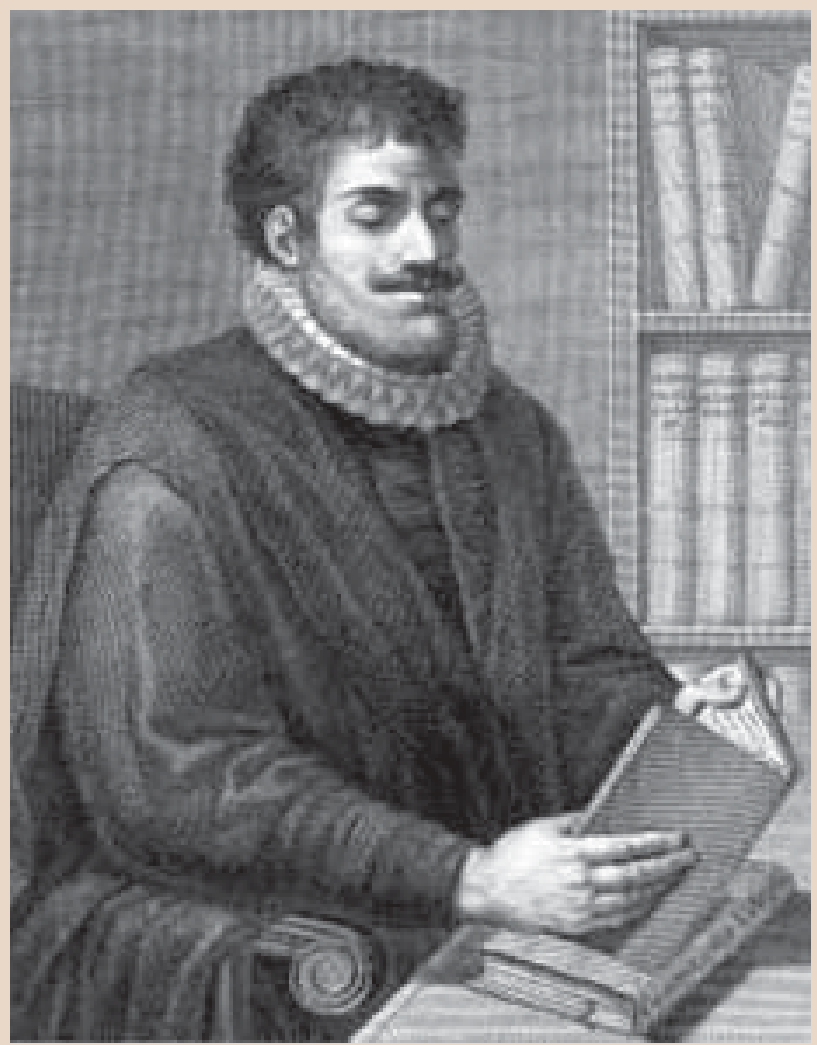

F. Sánchez de las Brozas (El Brocense)

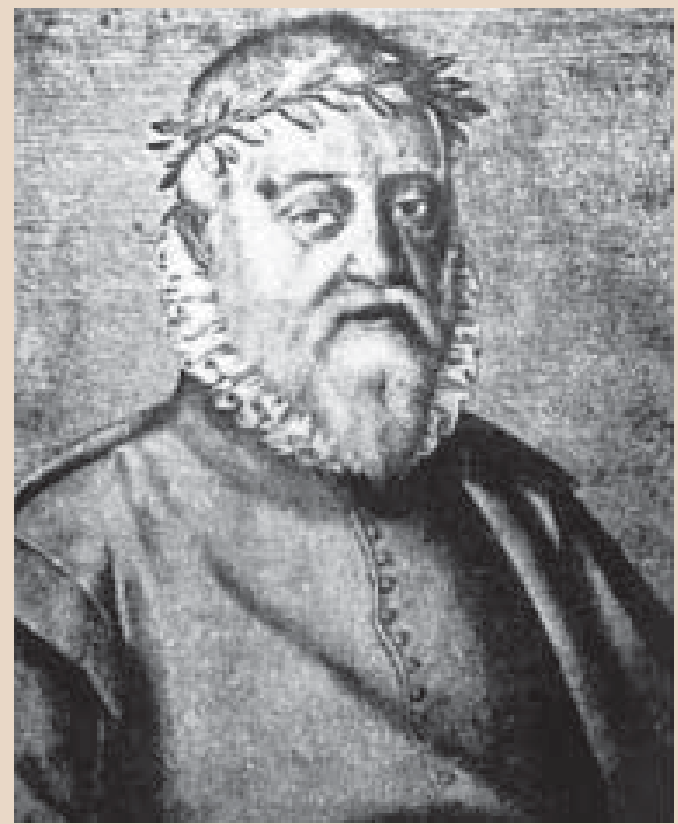

B. Alcázar

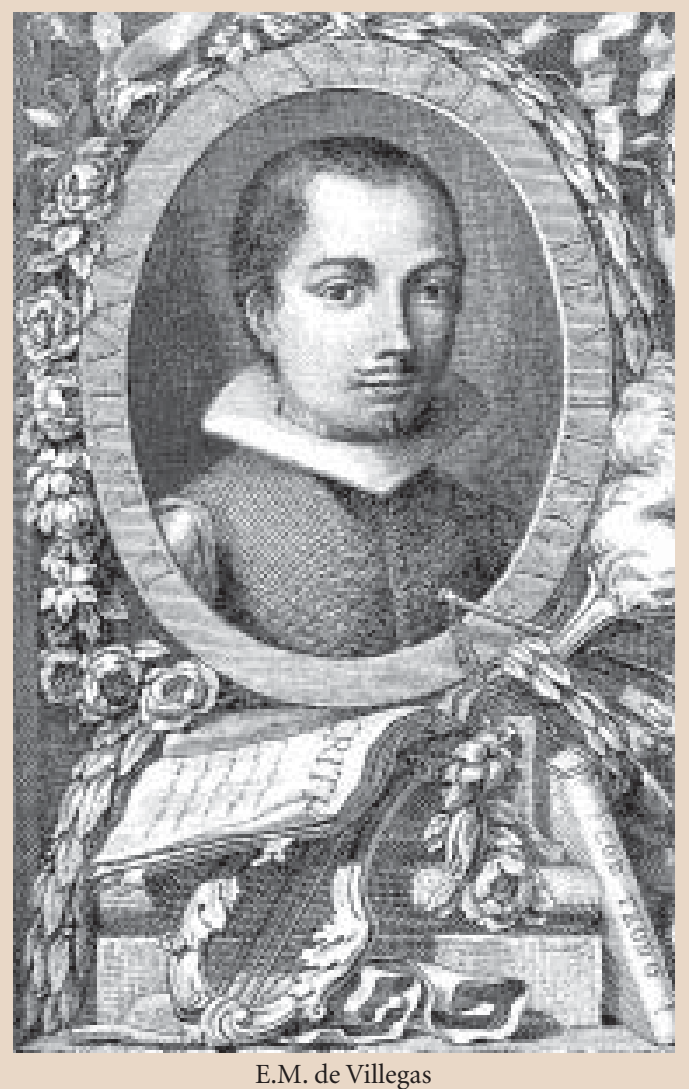




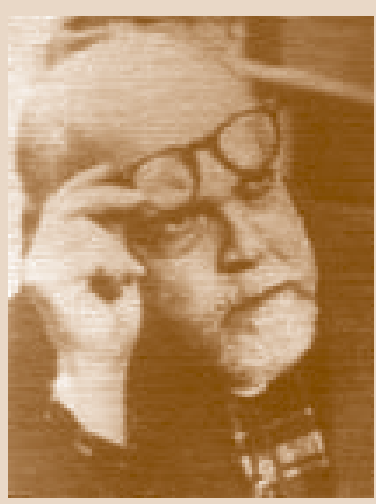

S. Reyes

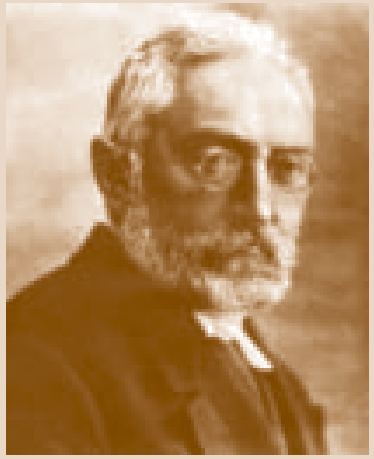

M. de Unamuno

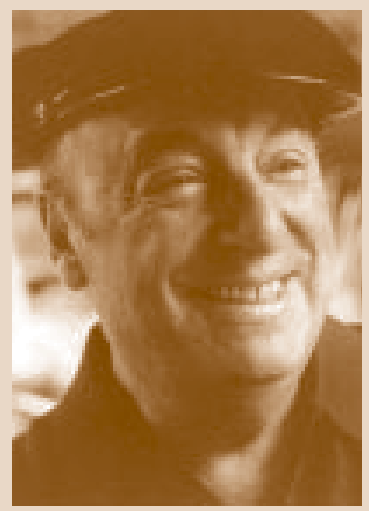

P. Neruda
Corren mis días en perfecta calma:

No halla el camino de mi pecho amor, y de sus tiros, victoriosa el alma, burla el rigor.

("El campanario", fragmento)

La estrofa sáfica también se cultivó en el Modernismo, aunque en menor medida que en los períodos anteriores. Tomás Navarro (1956) destaca esta forma métrica en el poema "Himno de la cigarra", de Alfonso Reyes, y en la oda de Marquina "A Espronceda, poeta civil”. Pero quien creó en estrofa sáfica con mayor prodigalidad fue Miguel de Unamuno, el que le introdujo varias modificaciones; sus poemas más conocidos de esta métrica son: "La torre de Monterrey a la luz de la luna", "La voz de la campana", "La hora de Dios" y "Salamanca" (1942: 56).

Alto soto de torres que al ponerse tras las encinas que el celaje esmaltan dora a los rayos de su lumbre el padre Sol de Castilla.

\section{(“Salamanca”)}

Unamuno usó con libertad la rima de los endecasílabos, multiplicando así las variedades de la estrofa sáfica; hizo pentasílabos esdrújulos, enlazó versos finales con rima asonante en las estrofas y otras variaciones que la alejan del modelo clásico.

En la poesía contemporánea Tomás Navarro cita dos poemas de Pablo Neruda: "Angela Adónica” y el poema elegíaco “Alberto Rojas Jiménez viene volando" (1956: 345), pero establece que estas estrofas sáficas están muy lejos del modelo clásico, si bien su estructura de tres endecasílabos y un pentasílabo suelto igualmente correspondería a este modelo:

Entre plumas que asustan, entre noches, entre magnolias, entre telegramas, entre el viento del sur y el oeste marino vienes volando.

"Alberto Rojas Jiménez viene volando" (fragmento)

El pentasílabo adónico: "vienes volando” es invariable en las veinte estrofas sáficas del poema, el que se inserta en Obras completas, Residencia en la Tie rra II (Neruda, 1962: 226). Del momento actual, Tomás Navarro rescata también el poema "Canción" de Florit, pero, como los poemas de Neruda ya mencionados, su estrofa sáfica dista de ser la auténtica, pues no observa el polirritmo, por lo que sus formas son sólo aparentemente sáficas; en cambio, califica de "auténtica forma de tres endecasílabos y un pentasílabo 
polirrítmicos sueltos" el poema de Ignacio Agustí “Cementerio de Soller” (Navarro, 1956: 466).

\section{EL TEXTO DEL POEMA FRENTE A LA ANTIPOETICA PARRIANA}

Se transcribe a continuación el texto completo del poema en estudio, copiado de Obra gruesa (Parra, 1969: 172-177):

Defensa de Violeta Parra

Dulce vecina de la verde selva huésped eterna del abril florido grande enemiga de la zarzamora Violeta Parra

Jardinera locera costurera

bailarina del agua transparente árbol lleno de pájaros cantores Violeta Parra

Has recorrido toda la comarca desenterrando cántaros de greda y liberando pájaros cautivos entre las ramas.

Preocupada siempre de los otros cuando no del sobrino de la tía cuándo vas a acordarte de ti misma Viola piadosa

Tu dolor es un círculo infinito que no comienza ni termina nunca pero tú te sobrepones a todo Viola admirable

Cuando se trata de bailar la cueca de tu guitarra no se libra nadie hasta los muertos salen a bailar cueca valseada 
Cueca de la batalla de Maipú cueca del Hundimiento del Angamos cueca del Terremoto de Chillán todas las cosas

Ni bandurria

ni tenca ni zorzal

Ni codorniza libre ni cautiva

tú

solamente tú

tres veces tú

Ave del paraíso terrenal

Charagüilla

gaviota de agua dulce

todos los adjetivos se hacen pocos

todos los sustantivos se hacen pocos

para nombrarte

Poesía

pintura

agricultura

todo lo haces a las mil maravillas

sin el menor esfuerzo

como quien bebe una copa de vino

Pero los secretarios no te quieren y te cierran las puertas de tu casa y te declaran la guerra a muerte Viola doliente.

Porque tú no te vistes de payaso porque tú no te compras ni te vendes porque hablas la lengua de la tierra Viola chilensis.

¡Porque tú los aclaras en el acto!

Cómo van a quererte me pregunto cuando son unos tristes funcionarios grises como las piedras del desierto ¿no te parece? 
En cambio tú

Violeta de los Andes

flor de la cordillera de la costa

eres un manantial inagotable

de vida humana.

Tu corazón se abre cuando quiere tu voluntad se cierra cuando quiere $y$ tu salud navega cuando quiere aguas arriba!

basta que tú los llames por sus nombres para que los colores y las formas se levanten y anden como Lázaro en cuerpo y alma...

¡Nadie puede quejarse cuando tú cantas a media voz, o cuando gritas como si te estuvieran degollando Viola volcánica!

Lo que tiene que hacer el auditor es guardar un silencio religioso porque tu canto sabe a dónde va perfectamente.

Rayos son los que salen de tu voz hacia los cuatro puntos cardinales vendimiadora ardiente de ojo negros Violeta Parra.

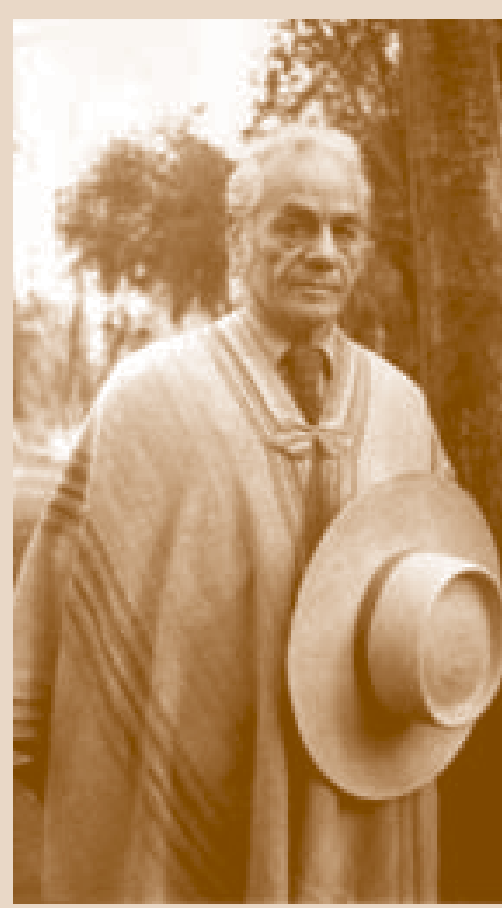

N. Parra

Se te acusa de esto y de lo otro yo te conozco y digo quien eres ¡oh corderillo disfrazado de lobo! Violeta Parra.

Yo te conozco bien

hermana vieja

norte y sur del país atormentado. Valparaíso hundido para arriba ¡Isla de Pascua!

Sacristana, cuyaca de Andacollo tejedora a bolillo y a palillo arregladora vieja de angelitos 
Los veteranos del setenta y nueve

lloran cuando te oyen sollozar

en el abismo de la noche oscura

¿Lámpara a sangre!

cocinera

$$
\text { niñera }
$$

lavandera

niña de mano

todos los oficios

todos los arreboles del crepúsculo

Viola funebris.

Yo no sé qué decir en esta hora la cabeza me da vueltas y vueltas como si hubiera bebido cicuta hermana mía.

Dónde voy a encontrar a otra Violeta aunque recorra campos y ciudades o me quede sentado en el jardín como un inválido.

Para verte mejor cierro los ojos y retrocedo a los días felices ¿sabes lo que estoy viendo? tu delantal estampado de maqui.

Tu delantal estampado de maqui ¡Río Cautín!

$$
\text { ¡Lautaro! }
$$

¡Villa Alegre!

Año mil novecientos veintisiete

Violeta Parra!

Pero yo no confío en las palabras ¿por qué no te levantas de la tumba a cantar

$$
\text { a bailar }
$$

en tu guitarra?

$$
\text { a navegar }
$$

Cántame una canción inolvidable una canción que no termine nunca una canción no más una canción

es lo que pido. 
Qué te cuesta mujer árbol florido

álzate en cuerpo y alma del sepulcro

y haz estallar las piedras con tu voz

Violeta Parra.

Esto es lo que quería decirte continúa tejiendo tus alambres tus ponchos araucanos tus cantaritos de Quinchamalí continúa puliendo noche y día tus toromiros de madera sagrada sin aflicción sin lágrimas inútiles

o si quieres con lágrimas ardientes y recuerda que eres un corderillo disfrazado de lobo.

Es procedente transcribir también el texto completo de la oda de Esteban Manuel de Villegas, que aparece en Las eróticas y amatorias, parte segunda (1913: 349), a fin de establecer cómo fue asimilada en el antipoema de Nicanor Parra. No nos fue posible probar si esta oda corresponde a una traducción de algún poeta griego o es una creación propia del "Anacreonte español", como se le llamaba a Villegas:

ODA AL CÉFIRO

Dulce vecino de la verde selva, huésped eterno del abril florido, vital aliento de la madre Venus, Céfiro blando.

Si de mis ansias el amor supiste, tú, que las quejas de mi voz llevaste, oye, no temas y a mi ninfa dile, dile que muero.

Así los dioses con amor paterno, así los cielos con amor benigno, nieguen al tiempo que feliz volares

Nieve a la tierra.

Jamás el peso de la nube parda, cuando amanece la elevada cumbre, toques tus hombros, ni su mal granizo hiera tus alas. 

Al confrontar los dos primeros versos de ambos poemas veremos que varía sólo el género: "Céfiro/vecino" con "Violeta/vecina", el primero referido al viento suave de la primavera, hijo de Eolo y de la Aurora, celebrado por los poetas griegos y latinos y, el segundo, a Violeta. Resulta una incoherencia el "abril florido" en el poema parriano, opuesto al "abril otoñal" amarillo por las hojas muertas de nuestro hemisferio.

Por menor pecado se acusó de plagio a otros poetas, pero creemos que aquí no corresponde este recurso descalificatorio, pues estamos ciertos que sin la intertextualidad anotada carecería del ritmo y la armonía que se aprecia en todos los niveles estructurales del poema parriano: estrófico, métrico y fónico, lo que permite que, independiente de la citada identidad, su valor estético sea indiscutible; realmente los dos versos iniciales parecen sólo anunciar la métrica clásica que tendrá el antipoema.

El diario La Discusión de Chillán publicó en primera página el texto completo del poema "Defensa de Violeta Parra", el 5 de octubre de 1969, con motivo del Premio Nacional de Literatura obtenido ese año por Nicanor Parra; posteriormente el poema fue grabado por un sello discográfico, recitándolo el propio poeta, por lo que logró gran difusión; además un fragmento de él formaba parte del repertorio de la folclorista argentina Mercedes Sosa, quien siempre lo incluía en sus recitales, por lo que es conocido a escala masiva dentro y fuera de Chile. En la obra parriana se encuentra en Obra gruesa, en el último conjunto de poemas antologados bajo el título "Otros poemas" (Parra, 1969).

También se incluye en la compilación de la obra de Parra efectuada por el crítico y escritor peruano Julio Ortega bajo el título Poemas para combatir la calvicie (Parra, 1993). El poema es inteligible para cualquier receptor, no tiene imágenes cifradas, ni "alquimia poética", ni "signos cabalísticos", consecuente con el arte de la antipoética y de acuerdo a su "Manifiesto"; sólo viola los principios de la antipoesía por encontrarse aferrado en su esquema métrico y rítmico a una "tabla vieja devuelta por el mar": la estrofa sáfica adónica que navega siglos desde una lejana isla del Mar Egeo. Postulamos el poema como una elegía antipoética enmarcada básicamente en la estructura tradicional de la estrofa sáfica adónica, cuya métrica ortodoxa se encuentra desplazada, fragmentada y diseminada en algunas de sus estrofas. Se tratará de establecer cuánto tiene el poema en estudio de "antipoesía", apoyándonos en la sistematización de las estructuras formales antipoéticas del profesor Leonidas Morales, en su estudio La poesía deNicanor Parra (1972: 4556), aun cuando debe tenerse presente las limitaciones que el motivo elegíaco impone, el que no puede contener el "chiste gozoso" o "el elemento picaresco". El recurso antipoético de apelación al lector como una forma de retrotraerlo al terreno de lo vulgar y cotidiano se sustituye en el poema por una acuciante apelación a Violeta y a sí mismo: "Cómo van a quererte / me pregunto / Cuando son unos tristes funcionarios". Pero si no existen las pre- 
guntas sarcásticas es posible encontrar la otra forma que crea también distanciamiento y rompe la ilusión estética: la mezcla de lo "grave y lo vulgar". Para ejemplificar este rasgo antipoético tomemos la primera estrofa que se inicia con la intertextualidad altamente lírica de los dos primeros versos precitados de Villegas de la "Oda al céfiro": "Dulce vecino(a) de la verde selva, / Huésped eterno(a) del abril florido", tensión lírica que se rompe con los versos siguientes: "Grande enemiga de la zarzamora", luego la síntesis de los tres versos anteriores, lo lírico y lo antipoético, lo estético y "el lenguaje de todos los días" aglutinados en un nombre: "Violeta Parra", correspondiente al verso adónico pentasílabo de la estrofa sáfica. El tercer verso no encierra una metáfora con todas las connotaciones semánticas que encierra la palabra "zarzamora", aunque tampoco pueden ser excluidas, sino, de acuerdo a lo que supimos, correspondería a un hecho puntual, pues Violeta pidió a su hermano eliminara las invasoras zarzamoras de su parcela en La Reina.

El recurso anteriormente señalado de ruptura o quiebre lírico está presente en forma mesurada, es decir, no tan violentamente como en otros antipoemas, pero, aún así, es posible encontrarlo en más de una estrofa: "Poesía / pintura / agricultura / Todo lo haces a las mil maravillas", para a continuación romper el tono lírico con el cambio a un lenguaje coloquial, casi vulgar: "sin el menor esfuerzo / Como quien se bebe una copa de vino".

Siguiendo el ordenamiento de los elementos estructurantes del antipoema, corresponde abocarse a lo narrativo, lo que radica en un hablante lírico transfigurado en un narrador, como un personaje activo, dramatizando lo que cuenta o testimonia, rasgo antipoético que, según Leonidas Morales (1972: 47), Pedro Lastra fue el primero en advertir. Lo testimonial se presenta como un inventario de todo el ser y el quehacer de Violeta Parra, una larga lista de oficios, algunos tan insólitos como: "Sacristana cuyaca de Andacollo / tejedora a palillo y a bolillo / arregladora vieja de angelitos"; narra los dolores, las frustraciones frente a los burócratas: "Pero los secretarios no te quieren / y te cierran las puertas de tu casa / y te declaran la guerra a muerte". El quehacer artístico de su hermana lo testimonia así: "Has recorrido toda la comarca / desenterrando cántaros de greda / y liberando pájaros cautivos / entre las ramas". Narra sencillamente los rasgos solidarios y humanos de Violeta: "Preocupada siempre de lo otros /cuando no del sobrino / de la tía", para luego coloquialmente apostrofarla "cuándo vas a acordarte de ti misma / Viola piadosa". Los atributos del genio de su hermana son relatados o testificados con menor distanciamiento síquico que en otros antipoemas, pues hay un temple anímico emotivo involucrado ante una situación inmediata y real: "yo no sé qué decir en esta hora / la cabeza me da vueltas y vueltas".

Tampoco está ausente la interferencia antipoética, la que Leonidas Morales denomina "prosaísmo" y que surge como correlato de lo narrativo, 
especialmente en los versos que se identifican con lugares comunes, como por ejemplo: "cuándo vas a acordarte de ti misma", "Y te declaran la guerra a muerte", "Se levante y ande como Lázaro", "Como si te estuvieran degollando", "Oh corderillo disfrazado de lobo", "La cabeza me da vueltas y vueltas", etc.

La "moraleja", otra de la formas antipoéticas, no está presente en este antipoema, tal vez debido a su contenido elegíaco, pero sí el verso final es una síntesis descriptiva y podría considerarse como tal expresado con un lugar común: "un corderillo disfrazado de lobo", resumen del testimonio del ser humano que fue Violeta.

Es necesario establecer que la "acumulación" como suma de elementos heterogéneos no es desintegradora, sino que los avecinamientos fónicos o términos de un mismo campo semántico, presentes por aliteraciones, están dirigidos al objetivo de testimoniar el ser de Violeta. Por ejemplo, una homofonía que se expresa en forma anafórica señala algo muy chileno, como Violeta, la palabra "cueca": "Cueca de la batalla de Maipú", "cueca del Hundimiento del Angamos / cueca del Terremoto de Chillán / todas las cosas". Existe otra acumulación donde se repelen heterogéneos contendientes que apuntan al ser y al no ser de Violeta: "Porque tú no te vistes de payaso / porque tú no te compras ni te vendes / porque hablas la lengua de la tierra / / Viola chilensis". Todo el antipoema es una acumulación de oficios y de cualidades que amplifican la descripción y testimonian quién fue realmente Violeta Parra, tarea que el hablante estima imposible debido a su desconfianza en el lenguaje, actitud básica del antipoeta: "Toda comunicación viene a ser un simulacro en la medida en que nos propone remedos de palabras, significaciones bastardas, pensamientos fariseos" (Morales, 1972: 65). La realidad ontológica es lo único auténtico: "Pero yo no confío en las palabras / ¿por qué no te levantas de la tumba / a cantar / a bailar / a navegar / en tu guitarra? / / Cántame una canción inolvidable / una canción que no termine nunca / una canción no más / una canción / es lo que pido". El pentasílabo adónico final corresponde a una expresión prosaica de plurivocidad, como la llama Segre (1984), que cumple aquí la función de romper la tensión lírica de los versos anteriores. La "imagen antipoética", la que, según Morales (1972: 54), “... se plantea rotunda y escueta delante de él como un objeto visual de raíz onírica, levemente gris, sin aureolas retóricas, pero extraordinariamente eficaz", se ajusta con todas estas características en el poema en estudio, como por ejemplo: "Porque tú no te vistes de payaso", imagen que nos comunica plásticamente con la representación de una figura pintarrajeada y vestida extravagantemente; otra imagen visual: "como quien se bebe una copa de vino", donde resulta difícil no imaginar el acto de la mano alzándose con la copa hacia los labios, o bien: "como si te estuvieran degollando", lugar común que adquiere en el texto antipoético gran fuerza 
expresiva por la dramática imagen plástica que comunica; "Valparaíso hundido para arriba", metáfora polisemántica que apunta a una visión plástica de la elevada belleza de los cerros del puerto, los que en su altura están sumidos o "hundidos" en la pobreza que en alguno de ellos existe. La tremendista representación del acto de cantar de Violeta, visualizado como: "Rayos son los que salen de tu voz". A fin de hacer más breve esta revisión de las imágenes como objeto visual, nos detendremos en el último verso de la estrofa número 27: "Para verte mejor cierro los ojos" (versos 126-7), con repercusión en el primer verso de la estrofa siguiente en que la remembranza y que se llena de hondo contenido nostálgico ante la visión de la infancia campesina, la que se hace presente en una nítida imagen plástica: “isabes lo que estoy viendo? / tu delantal estampado de maqui", el impulso emocional queda repercutiendo en el verso que inicia la estrofa siguiente: "Tu delantal estampado de maqui", recuerdo que se asocia a los lugares en donde transcurrió la infancia compartida: “¡ Río Cautín! / ¡Lautaro! / ¡Villa Alegre!”. En síntesis, las estructuras formales internas de "Defensa de Violeta Parra" se ciñen a la estética de la antipoesía, si bien no están presentes el humor y la ironía, debido al tema que la motiva, pero es posible encontrar las otras formas antipoéticas como: mezcla del lenguaje lírico con el cotidiano, distanciamiento, limitado por el tema que involucra emocionalmente al hablante; narración o testimonio del ser de Violeta; prosaísmo manifiesto en algunos casos con giros del habla coloquial o lugares comunes; léxico que apunta a realidades ontológicas y, finalmente, imágenes escuetas como representaciones plásticas o hechos puntuales de la realidad carentes de complejidad semántica.

\section{FORMA DE ASIMILAR EL MODELO METRICO SAFICO ADONICO EN EL ANTIPOEMA}

El antipoema que nos ocupa, desde el punto de vista de la conformación rítmica -lo que involucra el acento, la rima, el cómputo silábico, la pausa y el tono en los versos-, como ya lo hemos señalado reiteradamente, pertenece al modelo clásico de la estrofa sáfica adónica, según la define Tomás Navarro (1956: 192): "consta de cuatro versos sueltos, los tres primeros endecasílabos sáficos y el cuarto pentasílabo dactílico, llamado generalmente adónico".

Pero donde mejor y más prolijamente se la define es en una nota que encontramos a pie de página del extenso poema elegíaco de José María Vaca de Guzmán titulado "A la muerte de José Cadalso", que figura en una antigua edición de Poetas líricos siglo XVIII, tomo I (Vaca de Guzmán, 1869: 2912). El poeta acota: 
(Nota 8) Forman estos versos castellanos de artificio latino. Son unos sáficos, si no común composición de nuestros poetas, no desconocida de ellos, pero con la novedad del adorno de la asonancia, medio generalmente preferible a mi oído entre las vehemencias de las consonancias y disonancias de la soltura (...) y vienen a ser el oído esclavo de la reflexión. También prevengo a Ud. no tengo por versos sáficos a todos los que vea bautizados con este nombre, porque creen muchos y creen mal, (...) que lo son todos los endecasílabos, necesitan para serlo la buena disposición de los tiempos de la pronunciación, combinando la naturaleza de los asuntos con la exigencia del contexto. He procurado cumplir con estas reglas cuya transgresión es perceptible no sólo al que entiende su economía y sepa explicarla con términos poéticos, según los principios, sino al que tenga un oído medianamente arreglado, que seguramente distinguirá en el sáfico un sonido del que carecen muchos, aunque no todos los endecasílabos castellanos.

Antonio Quilis, en su M étrica española (1969: 97-98) define la estrofa sáfica en iguales términos que Tomás Navarro (1956: 192), señalando que trata de imitar los metros clásicos y que aparece en España en el siglo XVI, de lo que se dio cuenta en el apartado que se refiere a la trayectoria histórica de esta métrica. Agrega, sí, que sólo a partir del Neoclásico, cuenta con rima entre el primer y tercer endecasílabo. No podemos detenernos a examinar todos los cambios que los versos sáficos han experimentado en su largo recorrido histórico, pero sí es interesante conocer cómo se presentan estas innovaciones en el antipoema objeto de este estudio. El texto antipoético que se analiza consta de treinta y una estrofas, dieciocho de las cuales se ciñen a la métrica clásica, cuya definición se insertó anteriormente, caracterizada en detalle en nota transcrita más arriba del poeta José María Vaca de Guzmán. Nicanor Parra toma como modelo, reiteramos, al poeta renacentista Esteban Manuel de Villegas, en su "Oda al Céfiro", considerado como el epónimo de la métrica sáfica para la poesía hispana. Al esquema que se ciñe es el siguiente:

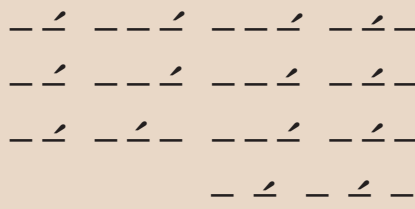

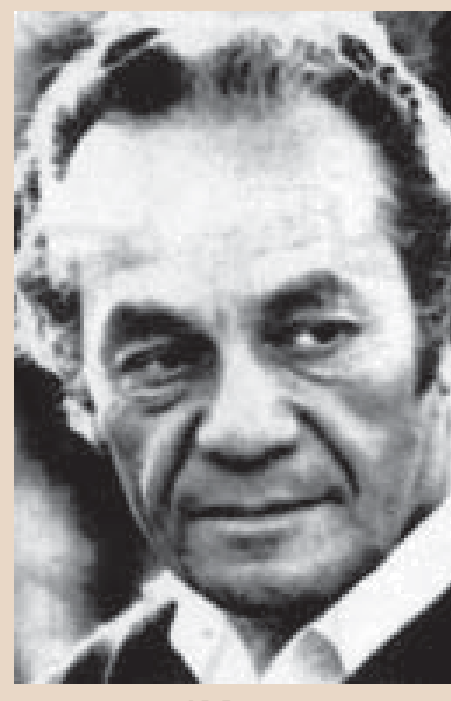

N. Parra

A este esquema métrico de versos sueltos se adscribe dieciocho de las treinta y una estrofas del antipoema en estudio: 
Dulce vecina de la verde selva huésped eterna del abril florido grande enemiga de la zarzamora Violeta Parra

La puntuación se ha suprimido totalmente y en trece estrofas, del total de treinta y una, los endecasílabos sáficos se han fragmentado y diseminado en diferentes tipos de líneas versales, predominantemente escalonadas:

jardinera

locera

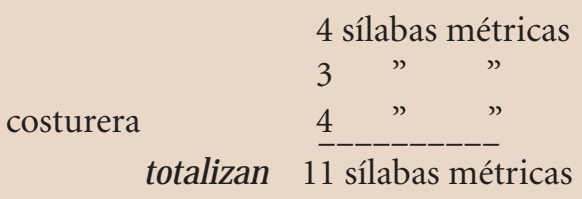

4 sílabas métricas

4 " "

11 sílabas métricas

El endecasílabo se ha fragmentado en tres líneas poéticas de 4-3-4 sílabas métricas y el acento se ha desplazado de la tercera, sexta y décima sílaba, a fin de presentar una aparente heterometría y con una ordenación de evidente efecto visual, pero su lectura nos devuelve el ritmo del endecasílabo sáfico que subyace.

Otros versos diseminados en diferentes disposiciones dentro de la estrofa sáfica, a fin de amortiguar y aflojar la tensión lírica, preocupación de la estética de la antipoesía parriana.

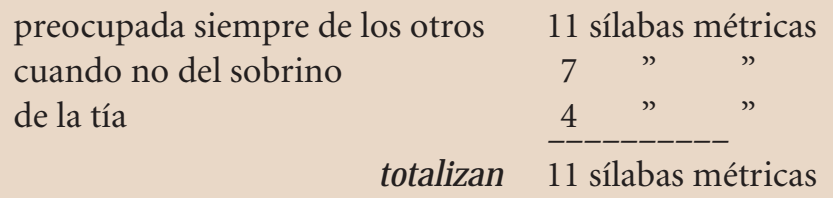

El endecasílabo se ha dividido en dos fragmentos de 7 y 4 sílabas métricas.

En la siguiente estrofa la diseminación es casi total:

Ni bandurria

ni tenca
4 sílabas métricas

3 " ”

ni zorzal

totalizan 11 sílabas métricas

Las tres líneas poéticas anteriores corresponden a un endecasílabo sáfico. El verso siguiente, en cambio, no se ha fragmentado: 
Pero las siguientes líneas poéticas pueden reunirse en un endecasílabo sáfico:

tú

solamente tú

tres veces tú

$$
\begin{aligned}
& 1 \text { sílaba métrica } \\
& \text { (4+1) } \frac{5}{5} " \text { ” " } \\
& 11 \text { sílabas métricas }
\end{aligned}
$$

$\mathrm{Al}$ recuento silábico métrico de las tres líneas poéticas anteriores, considerando el acento oxítono, se le ha sumado en cada caso una sílaba métrica, resultando así un endecasílabo sáfico. El endecasílabo sáfico siguiente se distribuyó gráficamente escalonado con el fragmento anterior:

tres veces tú.

Ave del paraíso terrenal
5 sílabas métricas

$$
10+111 ” \quad \cdots
$$

Prevalece el acento oxítono sólo en los dos versos finales de los endecasílabos, por lo que recobra la métrica sáfica. Algunas estrofas se hallan fundidas, pero igualmente conservan su estructura clásica:
Los veteranos del setenta y nueve lloran cuando te oyen sollozar en el abismo de la noche oscura ¡Lámpara a sangre! cocinera niñera lavandera niña de mano todos los oficios

\begin{tabular}{|c|c|c|c|}
\hline \multirow[b]{2}{*}{$(10+1)$} & \multicolumn{3}{|c|}{11 sílabas métricas } \\
\hline & 11 & $"$ & $"$ \\
\hline & 11 & " & $"$ \\
\hline & 5 & $"$ & $"$ \\
\hline & 4 & & \\
\hline & 3 & & \\
\hline & 11 & $”$ & $"$ \\
\hline & & & \\
\hline & 11 & ” & $"$ \\
\hline & 11 & $"$ & $"$ \\
\hline & 5 & $"$ & $"$ \\
\hline
\end{tabular}

todos los arreboles del crepúsculo Viola funebris

La estrofa final cuenta con once líneas poéticas de versos heterométricos, predominando los endecasílabos sáficos, uno de los cuales se presenta fragmentado en dos líneas poéticas:
3 silábas métricas

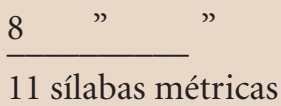


Carece de sentido examinar una a una las estrofas que presentan aparente heterometría, y decimos aparente, porque por debajo subyace la métrica sáfica adónica, la que al fragmentarse ha roto el sistema convencional de organizar el endecasílabo sáfico creando un ritmo diferente, el que podríamos denominar antimétrico.

La fragmentación del endecasílabo no sólo se expresa en una grafía escalonada o diseminada, acorde a la antipoesía, sino que se manifiesta como una fuerza expresiva que radica en la ruptura del código métrico clásico, mediatizada por una nueva sintaxis que tiende a la yuxtaposición, donde la entonación y las pausas expresan la unidad oracional de sentido:

$\begin{array}{ccc}\text { jardinera } & & \\ & \text { locera } & \\ & & \text { costurera }\end{array}$

bailarina del agua transparente

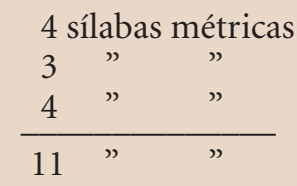

$11 ” \quad \cdots$

Se debe dejar claramente establecido que se ha denominado antimetría por el hecho de romper un esquema métrico clásico, consagrado por la tradición, ya que al fraccionarse el endecasílabo sáfico se altera su sintaxis, fenómeno métrico que no debe confundirse con la "ametría" del verso libre, pues éste no reconoce una matriz métrica, dejando así en evidencia lo que el propio poeta proclama en uno de sus Artefactos, ser "el gran desendecasílabador". Se puede concluir con la paradoja siguiente: el poema del cual nos ocupamos se estructura sobre la desarticulación de la métrica de un modelo clásico, de lo que resulta, desde el punto de vista de su estructura métrica, estar construido con la "demolición" de una larguísima tradición métrica.

\section{CONCLUSION}

A través del dilatado recorrido histórico del modelo métrico de la estrofa sáfica adónica, se estableció que con posterioridad al siglo XVI fue objeto de varias innovaciones con relación a su ritmo y a su rima, pero siempre se respetó su estructura versal básica, por lo que el poema de Nicanor Parra objeto de este estudio introduce una nueva y más audaz innovación que afecta la disposición del verso endecasílabo. De ello se desprende que los modelos métricos clásicos constituyen códigos irrenunciables como la lengua misma, que los poetas aceptan como un legado que puede ser sometido a innovaciones o variaciones y cuyos correlatos son sus estéticas y sus estilos. 
Concluimos al revisar las estructuras formales del poema "Defensa de Violeta Parra" que se adscribe a la antipoesía, por contar con un buen número de elementos acordes a esta estética, pero se reconoció a la vez que su mayor innovación rupturista residía en su métrica, resultante de la descomposición de un modelo consagrado por la tradición clásica, originando una nueva estructura versal, la que llamamos antimétrica, por formarse de las fragmentaciones y diseminaciones del endecasílabo clásico.

El nuevo elemento antipoético que denominamos antimétrica no debe confundirse con la "ametría" del versolibrismo; en el antipoema estudiado se han desestructurado los endecasílabos sáficos, creando una nueva estrofa de raíz sáfica.

De las identidades textuales entre una oda clásica y un antipoema se puede inferir una decidida voluntad de revelar fuentes para establecer la irrenunciable necesidad de continuar la tradición que ofrece el legado cultural.

En la poesía de Nicanor Parra se ha puesto el énfasis en lo absoluto de lo "antipoético", en lo rupturista, sin detenerse a ver cómo y cuáles son los modelos que el antipoeta devasta. El fenómeno poético es más complejo, sobre todo en poemas de largo aliento como el estudiado, porque las rupturas y las discontinuidades deben realizarse, necesariamente, a partir de modelos consagrados que atraviesan el nivel de lo inconsciente colectivo.

En síntesis, se puede concluir que los modelos fijados en determinadas formas en el funcionamiento de la cultura pueden ser sometidos a diversas alteraciones, incluso a descomposiciones, pero sin dejar de subyacer en ellos la diacronía cultural de que son portadores, pese a las mutabilidades que les impone el dinamismo inherente a la evolución humana en su afán de creación.

\section{REFERENCIAS}

Carrasco, Iván. 1999. Para leer a Nicanor Parra. Santiago de Chile: Ediciones Universidad Andrés Bello / Editorial Cuarto Propio. 233 pp.

Fernández, Maximino. 1980. "Fichas bibliográficas sobre Parra". Revista Chilena de Literatura No 15 , abril, pp. 107-131.

. 1984. "Fichas bibliográficas sobre Parra II". Revista Chilena de Literatura № 23, abril, pp. 141-147. . 1995. "Fichas bibliográficas sobre Parra III". Revista Chilena de Literatura No 47 , noviembre.

Halicarnaso, Dionisio de. 1884. Varios. Poetas líricos griegos. Tomo LXIX. Madrid: Biblioteca Clásica.

Morales, Leonidas. 1972. La poesía deN icanor Parra. Santiago de Chile: Universidad Austral de Chile / Editorial Andrés Bello. Colección Anejos de Estudios Filológicos No 4, serie Studia No 3. 
Navarro T., Tomás. 1956. M étrica española. Nueva York: Syracuse University Press. Centro de Estudios Hispánicos.

Neruda, Pablo. 1962. O bras completas. Buenos Aires: Losada. $2^{\text {a }}$ edic.

Parra, Nicanor. 1969. O bra gruesa. Santiago de Chile: Editorial Universitaria, Colección Cormorán.

. 1993. Poemas para combatir la calvicie. México: Fondo de Cultura Económica. Antología de poemas de N. Parra compiladas por Julio Ortega.

Quilis, Antonio. 1969. M étrica española. Madrid: Alcalá.

Segre, Cesare. 1984. Principios de análisis del texto literario. Barcelona: Crítica Grupo Editorial Grijalbo. Traducción castellana de María Pardo de Santayana.

Silva Castro, Raúl. 1959. Antología general dela poesía chilena. Santiago de Chile: Edit. Zig-Zag.

Unamuno, Miguel de. 1942. Antología poética. Madrid: Escorial.

Vaca de Guzmán, José María. 1869. Poetas líricos siglo XVIII , tomo I. Madrid: Biblioteca de Autores Españoles (Recopilación de M. Rivadeneira).

Villegas, Esteban Manuel de. 1913. Laseróticas o amatorias. Madrid: Ed. La Lectura. 